\title{
SENSORY ACCEPTANCE OF MIXED NECTAR OF PAPAYA, PASSION FRUIT AND ACEROLA
}

\author{
Fernando César Akira Urbano Matsuura ${ }^{1}$; Marília Ieda da Silveira Folegatti ${ }^{*}$; Ricardo Luís \\ $\mathrm{Cardoso}^{3}$; Daniel Costa Ferreira ${ }^{3}$ \\ ${ }^{1}$ Embrapa Mandioca e Fruticultura, C.P. 07 - 44380-000 - Cruz das Almas, BA - Brasil. \\ ${ }^{2}$ Embrapa Meio Ambiente, C.P. 69 - 13820-000 - Jaguariúna, SP - Brasil. \\ ${ }^{3}$ UFBA/Escola de Agronomia - Departamento de Química Agrícola, C.P. 082 - 44380-000 - Cruz das Almas, BA - \\ Brasil. \\ *Corresponding author <marilia@cnpma.embrapa.br>
}

\begin{abstract}
Nectars are beverages formulated with the juice or pulp of one or more fruits, plus water and sugar in concentrations resulting in a "ready-to-drink" product. Recently, the market for such products has greatly expanded. Fruit mixtures present a series of advantages, such as the combination of different aromas and flavors and the sum of their nutritional components. The objective of this work was to develop a nectar based on papaya pulp and passion fruit juice, enriched with the vitamin $C$ present in acerola pulp, optimizing the formulation using sensory consumer tests and a response surface statistical methodology. Eleven formulations were prepared using different concentrations of papaya pulp and passion fruit juice and sucrose, and maintaining the concentration of acerola pulp constant. The sensory tests were carried out with 22 nontrained panelists using a structured 9-point hedonic scale to evaluate overall acceptance. The acceptance means were submitted to regression analysis, by first calculating a polynomial quadratic equation. A predictive model was adjusted considering only those parameters where $P \leq 0.05$, and a response surface was generated. The overall acceptance of nectars of different formulations varied from 5 ("neither liked nor disliked") to more than 7 ("liked moderately"), showing that some products can be considered adequate to consumers, like the nectar produced with $37.5 \%$ papaya pulp, $7.5 \%$ passion fruit juice, and 5.0\% acerola pulp, added of $15 \%$ sucrose. A quadratic predictive overall acceptance model, with a regression coefficient of 0.97 was obtained. The sensory acceptance of nectars was positively affected by increases in the concentrations of papaya pulp and of sucrose. Thus, some products presented good sensory acceptance suggesting commercial potential. Key words: beverage, ready-to-drink, tropical fruit, blend
\end{abstract}

\section{ACEITAÇÃO SENSORIAL DE UM NÉCTAR MISTO DE MAMÃO, MARACUJÁ E ACEROLA}

RESUMO: Néctar é uma bebida formulada com suco ou polpa de uma ou mais frutas, água e açúcar, em concentrações tais que resultem em um produto "pronto-para-beber". Recentemente, o mercado para este produto de conveniência tem se expandido de forma expressiva. As misturas de frutas apresentam uma série de vantagens, como a combinação de diferentes aromas e sabores e a soma de componentes nutricionais. O objetivo deste trabalho foi desenvolver um néctar à base de polpa de mamão e suco de maracujá, fortificado com vitamina $\mathrm{C}$ presente na polpa de acerola, otimizando sua formulação através de testes sensoriais com consumidores e usando metodologia de análise estatística de superfície de resposta. Onze formulações foram elaboradas, empregando-se diferentes concentrações de polpa de mamão e de suco de maracujá e sacarose adicionada, mantendo-se constante a concentração de polpa de acerola. Os testes sensoriais foram realizados com 22 provadores não treinados, utilizando-se escala hedônica estruturada de nove pontos, para avaliação da aceitação global. As médias de aceitação foram submetidas a uma análise de regressão, calculando-se inicialmente uma equação polinomial quadrática. Um modelo preditivo foi ajustado considerando-se apenas os parâmetros com $P \leq 0,05$ e um gráfico de superfície de resposta foi traçado. A aceitação sensorial dos néctares das diferentes formulações variou de 5 ("nem gostei, nem desgostei") até mais de 7 ("gostei moderadamente"), mostrando que alguns produtos podem ser considerados adequados para os consumidores, como o néctar produzido com 37,5\% de polpa de mamão, 7,5\% de suco de maracujá e $5,0 \%$ de polpa de acerola, adicionado de $15 \%$ de sacarose. Um modelo preditivo quadrático da aceitação sensorial global, com coeficiente de regressão de 0,97 , foi obtido. A aceitação sensorial dos néctares foi positivamente afetada pelo aumento da concentração de polpa de mamão e de sacarose. Portanto, alguns produtos apresentaram boa aceitação sensorial, o que sugere potencial para aproveitamento comercial.

Palavras-chave: bebida, pronto para beber, fruta tropical, blenda

Sci. Agric. (Piracicaba, Braz.), v.61, n.6, p.604-608, Nov./Dec. 2004 


\section{INTRODUCTION}

Nectar is a non-fermented beverage, produced from the dissolution of the edible portion of the fruit and sugars in water, for direct consumption, and could be added of acid, respecting the characteristics and compositions established for each fruit, such as sensory attributes, juice content, soluble solids, total acidity, and total sugar (Brasil, 2003). Fruit blends present a series of advantages, such as the possibility of combining different aromas and flavors, plus the sum of nutritionally different components.

A study of different papaya nectar formulations showed an increase in sensory acceptance with increasing pulp content (up to 40\%) (Mostafa et al., 1997). Mixed nectars of papaya and mango pulps were studied (Mostafa et al., 1997), and products with equal amounts of both pulps and a total of $30 \%$ or $40 \%$ pulp in the formulation were best accepted, as compared to those with lower levels of mango pulp. Another study involving mixed nectar formulations containing papaya pulp and passion fruit juice showed better sensory acceptance to nectars containing higher proportions of papaya pulp. The products presented an ascorbic acid content varying from 35.4 to $36.8 \mathrm{mg} 100 \mathrm{~g}^{-1}$ (Salomon et al., 1977). These authors concluded that both papaya and passion fruit presented characteristics suitable for the preparation of mixed nectars.

A research using different nectars showed best sensory acceptance for a product formulated with papaya pulp and passion fruit juice (90:10 proportion) as compared to nectars produced with mango pulp and papaya pulp, passion fruit juice and pear juice, mango pulp and pear juice, and pear juice and papaya pulp (Imungi \& Choge, 1996). Nectars formulated with orange and passion fruit juices had a reduction in sensory acceptance for blends with an increased proportion of passion fruit juice, which was attributed to the strong flavor of the passion fruit juice (Shaw \& Wilson III, 1988).

Nectars produced with guava and papaya pulp (70:30) had a high sensory quality score, mainly due to consistency and flavor, and also because it contained fair amounts of vitamin C (24.7 mg $100 \mathrm{~g}^{-1}$ ) (Tiwari, 2000). A grape and guava juice blend was also used for jelly preparation, and products with a 40:60 ratio scored highest for color, flavor, consistency, and overall acceptance by sensory evaluation as compared with 20:80 and 60:40 ratios (Poonam et al., 1997). Acerola pulp is rich in vitamin C but has limited sensory appeal. Different authors have studied blends of acerola juice combined with various fruit juices and pulps (Sanches-Nieva, 1955; Matsuura et al., 1999; Folegatti et al., 2000; Matsuura \& Rolim, 2002). Besides increasing the vitamin $C$ content, the addition of acerola pulp improves the color and fla- vor of orange juices with low contents of solids (SanchesNieva, 1955; Ledin, 1958).

An optimized formulation for a mango and acerola nectar contained $9 \%$ acerola pulp, $15^{\circ}$ Brix, and an ascorbic acid content of $76 \mathrm{mg} 100 \mathrm{~g}^{-1}$ (Matsuura et al., 1999). The addition of acerola pulp up to a limit of $34 \%$ to a papaya and acerola nectar did not affect the sensory acceptance of the nectar and presented approx. 170 $\mathrm{mg} 100 \mathrm{~g}^{-1}$ ascorbic acid. The optimum level of sugar was between $8.5 \%$ and $16 \%$ (Folegatti et al., 2000). Pineapple juice (20.9 mg $100 \mathrm{~g}^{-1}$ ascorbic acid) added of $10.0 \%$ acerola juice $\left(1,000 \mathrm{mg} 100 \mathrm{~g}^{-1}\right.$ ascorbic acid) resulted in product with about five times the vitamin $\mathrm{C}$ content of pineapple juice, and sensorial analyses showed no difference between treatments (Matsuura \& Rolim, 2002).

The objective of this work was to develop a nectar based on papaya and passion fruit pulps, enriched with vitamin $\mathrm{C}$ present in acerola pulp, and to optimize the formulation using sensory consumer tests and a response surface statistical methodology.

\section{MATERIAL AND METHODS}

Commercial frozen pasteurized whole papaya pulp, passion fruit juice, and acerola pulp (Brasfrut company, Brazil), plus mineral water (Indaiá company, Brazil) and refined sugar (Copersucar company, Brazil) were used in this work.

\section{Experimental design}

The variables studied were proportion of papaya:passion fruit pulps and sucrose content. Eleven treatments were defined using a $2^{2}$ factorial design with 3 central points and two axial points per variable (Central Composite Design).

\section{Formulations}

Nine formulations were prepared, using different concentrations of papaya pulp (from $28.5 \%$ to $39.0 \%$ ), passion fruit juice (from $6 \%$ to $16.5 \%$ ), and sucrose (from $5 \%$ to $17 \%$ ), maintaining a constant acerola pulp concentration of $5 \%$. The sum of papaya pulp and passion fruit juice corresponded to $90 \%$ of the pulp and juice content in the formulation. The formulations contained a total of $50 \%$ fruit pulp-juice (papaya, passion fruit, and acerola) and $50 \%$ mineral water, plus different concentrations of sugar (Table 1).

\section{Physical, physicochemical and chemical analyses}

The papaya pulp, passion fruit juice, and acerola pulp, and the nectars were analyzed for $\mathrm{pH}$, total soluble solids as Brix (TSS), and total titratable acidity (TTA), according to the AOAC (1995), while ascorbic acid content was analyzed according to Benassi (1990). 


\section{Sensory analysis}

An acceptance test with 22 non-trained panelists was carried out using a 9-point structured hedonic scale ( 1 = "disliked extremely"; 9 = "liked extremely") for overall acceptance evaluation. The order of presentation of the samples was completely randomized for each panelist (Wakeling \& MacFie, 1995).

\section{Statistical analysis}

The results of the physical, physicochemical and chemical analyses were submitted to analysis of variance

Table 1 - Papaya, passion fruit, and acerola nectar formulations used in the treatments.

\begin{tabular}{|c|c|c|c|}
\hline Treatment* & Papaya pulp & Passion fruit juice & Sucrose \\
\hline & \multicolumn{3}{|c|}{ - } \\
\hline 01 & 30.00 & 15.00 & 7 \\
\hline 02 & 37.50 & 7.50 & 7 \\
\hline 03 & 30.00 & 15.00 & 15 \\
\hline 04 & 37.50 & 7.50 & 15 \\
\hline 05 & 33.75 & 11.25 & 11 \\
\hline 06 & 33.75 & 11.25 & 11 \\
\hline 07 & 33.75 & 11.25 & 11 \\
\hline 08 & 28.50 & 16.50 & 11 \\
\hline 09 & 39.00 & 6.00 & 11 \\
\hline 10 & 33.75 & 11.25 & 5 \\
\hline 11 & 33.75 & 11.25 & 17 \\
\hline
\end{tabular}

*The treatment formulations also included acerola pulp (5.00\%) and water (to complete to $100 \%$ ).
$(P \leq 0.05)$ and a means comparison test (Tukey) (Gomes, 1987). The acceptance means were submitted to regression analysis, by first calculating a polynomial quadratic equation and testing the lack of adjustment and significance of each parameter. A predictive model was adjusted considering only those parameters where $P \leq 0.05$, and a Response Surface was generated (Barros Neto et al., 1995).

\section{RESULTS AND DISCUSSION}

The nectars had $\mathrm{pH}$ values from 3.22 to 3.49 . A decrease in acidity was observed as the proportion of papaya pulp increased (above 33.75\%) in the nectar and consequently decreased in the amount of passion fruit juice (Table 2). Despite the variation in total titratable acidity of the products, values were all relatively low, from $0.33 \%$ to $0.63 \%$, showing that all nectars formulated could be recommended for consumption by children and by the elderly, as is the case with papaya pulp.

The total soluble solids content varied from $7.92^{\circ}$ Brix to $17.12^{\circ}$ Brix; the products are thus indicated for different consumers, submitted to diets with different calories. The total soluble solids contents of the formulated products varied mainly as a function of the amount of sugar added. These contents were similar to nectars produced with mango pulp and acerola pulp, and with papaya pulp and acerola pulp (Matsuura et al., 1999 and Folegatti et al., 2000).

Table 2 - pH, total soluble solids (TSS), total titratable acidity (TTA), and ascorbic acid (AA) values of different pulps or juices and nectars.

\begin{tabular}{|c|c|c|c|c|c|c|c|}
\hline Treatment / Material & Papaya pulp & Passion fruit juice & Sucrose & $\mathrm{pH}$ & TSS & TTA & AA \\
\hline Treatment (nectars) & \multicolumn{3}{|c|}{$\%$ added in formulation* } & & ${ }^{\circ}$ Brix & $\%$ & $\mathrm{mg} 100 \mathrm{~g}^{-1}$ \\
\hline 01 & 30.00 & 15.00 & 7 & $3.25 \mathrm{a}$ & $10.68 \mathrm{e}$ & $0.63 \mathrm{a}$ & $53.9 \mathrm{c}$ \\
\hline 02 & 37.50 & 7.50 & 7 & $3.49 \mathrm{a}$ & $10.28 \mathrm{e}$ & $0.38 \mathrm{e}$ & $62.7 \mathrm{ab}$ \\
\hline 03 & 30.00 & 15.00 & 15 & $3.22 \mathrm{a}$ & $16.44 \mathrm{ab}$ & $0.58 \mathrm{~b}$ & $64.9 \mathrm{a}$ \\
\hline 04 & 37.50 & 7.50 & 15 & $3.40 \mathrm{a}$ & $16.04 \mathrm{~b}$ & 0.36 ef & $59.9 \mathrm{~b}$ \\
\hline 05 & 33.75 & 11.25 & 11 & $3.31 \mathrm{a}$ & $14.92 \mathrm{c}$ & $0.50 \mathrm{~d}$ & $55.2 \mathrm{c}$ \\
\hline 06 & 33.75 & 11.25 & 11 & $3.33 \mathrm{a}$ & $13.60 \mathrm{~d}$ & $0.55 \mathrm{bc}$ & $54.6 \mathrm{c}$ \\
\hline 07 & 33.75 & 11.25 & 11 & $3.34 \mathrm{a}$ & $13.32 \mathrm{~d}$ & $0.51 \mathrm{~cd}$ & $54.3 \mathrm{c}$ \\
\hline 08 & 28.50 & 16.50 & 11 & $3.28 \mathrm{a}$ & $13.04 \mathrm{~d}$ & $0.61 \mathrm{ab}$ & $59.9 \mathrm{~b}$ \\
\hline 09 & 39.00 & 6.00 & 11 & $3.48 \mathrm{a}$ & $13.80 \mathrm{~d}$ & $0.33 \mathrm{f}$ & $60.2 \mathrm{~b}$ \\
\hline 10 & 33.75 & 11.25 & 5 & $3.43 \mathrm{a}$ & $7.92 \mathrm{f}$ & $0.52 \mathrm{~cd}$ & $59.8 \mathrm{~b}$ \\
\hline 11 & 33.75 & 11.25 & 17 & $3.34 \mathrm{a}$ & $17.12 \mathrm{a}$ & $0.48 \mathrm{~d}$ & $52.4 \mathrm{c}$ \\
\hline \multicolumn{8}{|l|}{ Material } \\
\hline West Indian cherry pulp & & & & 3.18 & 5.62 & 1.30 & 217.21 \\
\hline Papaya pulp & & & & 4.71 & 9.44 & 0.17 & 46.01 \\
\hline Passion fruit juice & & & & 2.93 & 11.30 & 3.69 & 19.99 \\
\hline
\end{tabular}

Means of three samples.

Treatments with different letters in the same column are different $(P<0.05)$.

*The treatment formulations also included acerola pulp (5.00\%) and water (to complete to $100 \%)$.

Sci. Agric. (Piracicaba, Braz.), v.61, n.6, p.604-608, Nov./Dec. 2004 
The ascorbic acid content also varied amongst the treatments, ranging from 52.4 to $64.99 \mathrm{mg}$ ascorbic acid in $100 \mathrm{~g}$; these values are equivalent to those found in whole orange juice, considered to be a good source of vitamin $C$, and were superior to guava and papaya nec$\operatorname{tar}$ (Tiwari, 2000). The products formulated with acerola pulp, such as the mixed nectars with apricot and pear juices and the mixed juice with grapefruit, developed by Sanches-Nieva (1955), also presented final ascorbic acid contents between 50-60 mg $100 \mathrm{~g}^{-1}$. A nectar with mango pulp and acerola pulp had an ascorbic acid content higher than $70 \mathrm{mg} 100 \mathrm{~g}^{-1}$ (Matsuura et al., 1999), while a nectar with papaya pulp and passion fruit juice had a con-

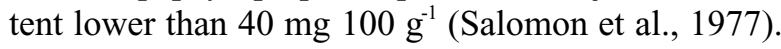

In this work, a commercial acerola pulp with an

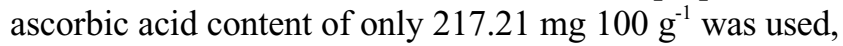
but commercial pulps with much higher values (more than $800 \mathrm{mg} 100 \mathrm{~g}^{-1}$ ) do exist, which would allow for the production of nectars with much higher final vitamin $\mathrm{C}$ contents, of approximately 200 to $250 \mathrm{mg} 100 \mathrm{~g}^{-1}$. Besides, a constant amount of $5 \%$ acerola pulp was added to the total pulp content of the formulation and future experiments could increase this amount. Probably, the sum of acerola pulp with higher values of ascorbic acid and an increase in the proportion of acerola pulp added to the formulation could result in nectars with extremely high vitamin $\mathrm{C}$ content, such as the results for pineapple juice added of acerola pulp (Matsuura \& Rolim, 2002), but the sensory acceptability of these products still has to be evaluated.

The sensory acceptance of nectars of different formulations varied from 5 ("neither liked nor disliked") to more than 7 ("liked moderately"). In particular, products with a high amount of papaya pulp or sucrose had good sensory acceptance with values near or superior to 7. The mixed nectars of orange and passion fruit juices, studied by Shaw \& Wilson III (1988), obtained sensory acceptance scores in the same range, between 5.1 and 6.8. In general, the acerola and papaya juices presented much lower sensory acceptance scores than the mixed products, showing a sinergistic effect of the fruit compounds in the mixed nectar. ceptance:

The following model was obtained for overall ac-

Overall acceptance $=6.89+0.40(\%$ papaya pulp $)$ $+0.75(\%$ sucrose $)-0.33(\% \text { sucrose })^{2}$. This model showed a regression coefficient of 0.97 . The $F$ value calculated from the analysis of variance of the model was many times greater than the tabulated $\mathrm{F}$ value. From the response surface graph (Figure 1), it can be seen that nectars with higher proportions of papaya pulp (tested up to $39 \%$ ) and sucrose (tested up to $17 \%$ ) were better accepted in the sensorial analysis, probably due to the lower acidity and better flavor quality of the products formulated with a higher proportion of papaya pulp.
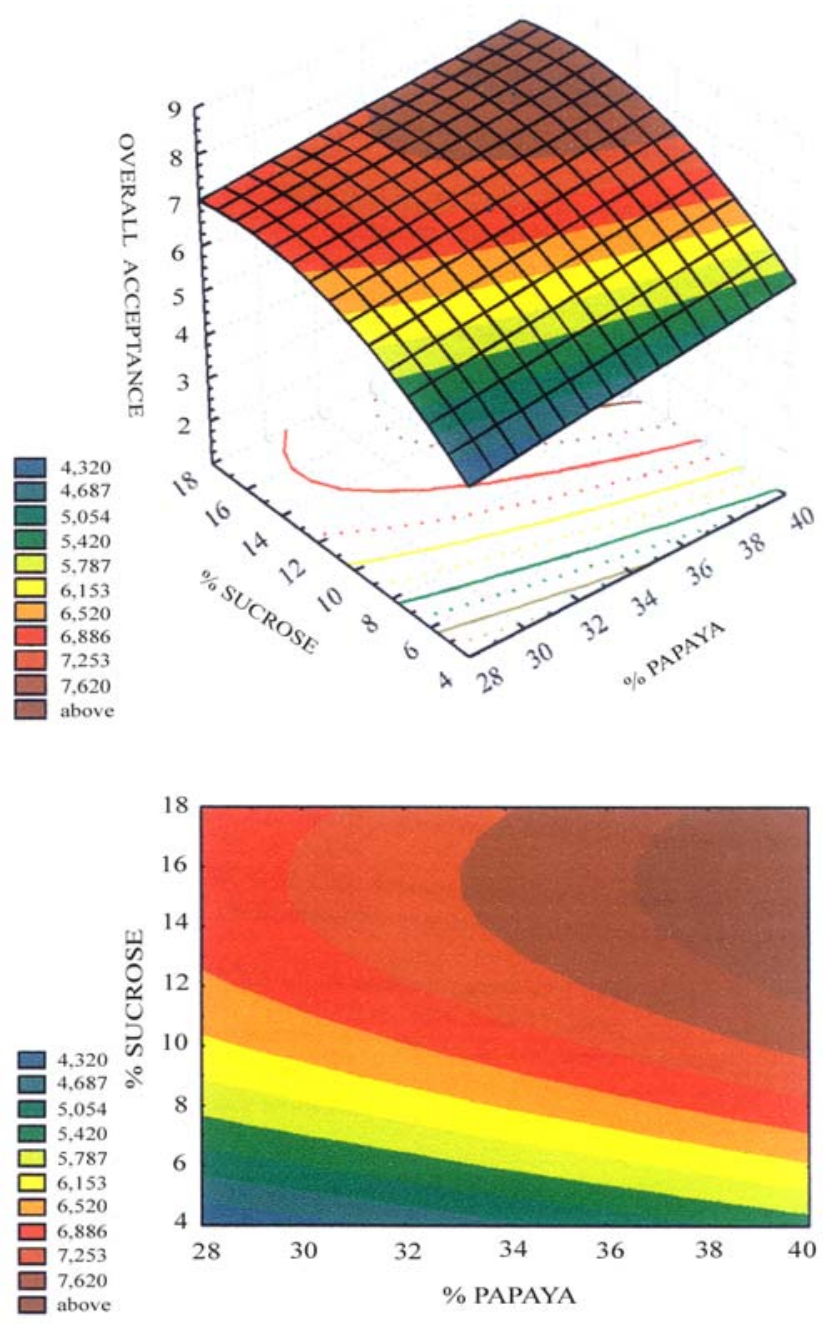

Figure 1 - Response Surface (A) and Contour (B) graphs for overall acceptance of the mixed nectars of papaya pulp, passion fruit juice, and acerola pulp.

The increase in sensory acceptance as the proportion of papaya pulp in the blend increased was also observed by Salomon et al. (1977). These authors observed that nectars with a high proportion of passion fruit juice:papaya pulp (25:75) were considered too acid. The same tendency was noticed with orange and passion fruit juice blends (Shaw \& Wilson III, 1988). In this work, however, nectars formulated with a higher proportion of passion fruit juice will maintain their sensory acceptance scores if there is an increase in the amount of sugar that is added in the formulation (Figure 1).

\section{CONCLUSIONS}

Some mixed nectars showed good sensory acceptance and a high vitamin $\mathrm{C}$ content, suggesting potential commercial success. Increased amounts of papaya pulp and sucrose positively influenced the sensory acceptance of the products (up to $39 \%$ and $17 \%$, respectively). 


\section{ACKNOWLEDGEMENTS}

To Brasfrut and Copersucar for providing the raw materials, and to Miss Bárbara S. dos Santos for her support in carrying out some analyses.

\section{REFERENCES}

ASSOCIATION OF OFFICIAL ANALYTICAL CHEMISTS. Official methods of analysis. 16. ed. Arlington: AOAC, 1995.

BARROS NETO, B.; SCARMINIO, I.S.; BRUNS, R.E. Planejamento e otimização de experimentos. Campinas: Editora da Unicamp, 1995. $299 \mathrm{p}$.

BENASSI, M.T. Análise dos efeitos de diferentes parâmetros na estabilidade de vitamina $\mathrm{C}$ em vegetais processados. Campinas: UNICAMP/FEA, 1990. 159p. (Dissertação - Mestrado).

BRASIL. Ministério da Agricultura, Pecuária e Abastecimento. Instrução normativa $n .^{\circ} 12$, de 4 de setembro de 2003 . Aprovar o regulamento técnico para a fixação de padrões de identidade e qualidade gerais de sucos tropicais e néctares e outros. Diário Oficial da União, 9 set. 2003. Seção 1, p.2.

FOLEGATTI, M.I.S.; FERREIRA, D.C.; MATSUURA, F.C.A.U. Otimização da aceitação de néctar de mamão e acerola através de metodologia de superfície de resposta. In: CONGRESSO BRASILEIRO DE CIÊNCIA E TECNOLOGIA DE ALIMENTOS, 17., Fortaleza, 2000 Anais. Campinas: SBCTA, 2000. v.1, p.319

GOMES, F.P. A estatística moderna na pesquisa agropecuária. 3.ed. Piracicaba: Potafos, 1987. 162p.

IMUNGI, J.K.; CHOGE, R.C. Some physico-chemical characteristics of four Kenyan tropical fruits and acceptability of blends of their beverage nectars. Ecology of Food and Nutrition, v.35, p.285-293, 1996

LEDIN, R.B. The Barbados or West Indian cherry. Gainesville: University of Florida, 1958. 17p. (Bulletin, 594).
MATSUURA, F.C.A.U.; ROLIM, R.B. Avaliação da adição de suco de acerola em suco de abacaxi visando a produção de um blend com alto teor de vitamina C. Revista Brasileira de Fruticultura, v.24, p.138$141,2002$.

MATSUURA, F.C.A.U.; FOLEGATTI, M.I.S.; CARDOSO, R.L.; DA SILVA, M.A.A.P. Otimização da aceitação de néctar de manga enriquecido com acerola através de metodologia de superfície de resposta e mapa de preferência. In: SIMPÓSIO LATINO AMERICANO DE CIÊNCIA DE ALIMENTOS, 3., Campinas, 1999. Anais. Campinas: Unicamp, 1999. p. 210

MOSTAFA, G.A.; ABD EL-HADY, E.A.; ASKAR, A. Preparation of papaya and mango nectar blends. Fruit Processing, v.5, p.180-185, 1997.

POONAM, A.; PADDA, G.S.; SIDHU, J.S. Standardization of jelly preparation from grape:guava blends. Journal of Food Science and Technology, v.34, p.335-336, 1997.

SALOMON, E.A.; KATO, K.; MARTIN, J.Z. de; SILVA, S.D. da; MORI, E.E.M. Estudo das composições (blending) do néctar de mamãomaracujá. Boletim do ITAL, v.51, p.165-179, 1977.

SANCHES-NIEVA, F. Extraction, processing, canning and keeping quality of acerola juice. Journal of Agricultural of the University of Puerto Rico, v.39, p.175-183, 1955 .

SHAW, P.E.; WILSON III, C.W. Sensory evaluation of passion fruit - orange juice blends. Lebensmittel Wissenshaft und Technologie, v.21, p.358359, 1988.

TIWARI, R.B. Studies on blending of guava and papaya pulp for RTS beverage. Indian Food Packer, v.54, p.68-72, 2000.

WAKELING, I.N.; MACFIE, J.H. Designing consumer trials balanced for first and higher orders of carry-over effect when only a subset of $\mathrm{k}$ samples from t may be tested. Food Quality and Preference, v.6, p.299308, 1995.

Received September 29, 2003

Accepted September 13, 2004 